III. Construction of a new imaginary of the city and public space: Saraus movement, mobility and religion

\title{
Lambadão:
}

\section{breaking the borders of the periphery}

\author{
Lidiane Freitas de Barros' \\ Patricia Silva Osório \\ Juliana Braz Dias 3
}

'Universidade Federal de Mato Grosso, Núcleo de Estudos de Cultura Popular - Caleidoscópio, Cuiabá/MT, Brasil

${ }^{2}$ Universidade Federal de Mato Grosso, Departamento de Antropologia, Cuiabá/MT, Brasil

3Universidade de Brasília, Departamento de Antropologia, Brasília/DF, Brasil

\begin{abstract}
Non hegemonic forms of musical production have appeared in peripheral regions of Brazil, such as the lambadão genre in the Mato Grosso state. Lambadão is a product of the lower classes that, without expecting recognition from the cultural industry, but in dialog with it, use their own devices to have their music be heard. The objective of this article is to analyze how lambadão is articulated and projected in the peripheries of Cuiabá and Várzea Grande. The recording of CDs at live performances or in home studios and the reproduction and sale of the recordings by street vendors are dynamic processes used to produce and promote this musical genre. Far from being mere responses to a situation of precariousness and marginality in the field of cultural production, these processes are creative practices that attend to differentiated value systems.
\end{abstract}

Keywords: Lambadão, Periphery, Popular Culture, Musical Production. 


\section{O lambadão:}

\section{rompendo as fronteiras da periferia}

\section{Resumo}

Formas não hegemônicas de produção musical têm surgido em regiões periféricas do Brasil, como é o caso do lambadão, no estado de Mato Grosso. O lambadão é produto de camadas populares que, sem esperar por reconhecimento da indústria cultural, mas em diálogo com ela, lançam mão de artifícios próprios para fazer sua música ecoar. O objetivo do artigo é analisar os modos como se articula e se projeta o lambadão nas periferias de Cuiabá e Várzea Grande. A gravação de CDs ao vivo ou em estúdios caseiros e a reprodução e venda dos discos por camelôs são dinâmicas acionadas para produzir e divulgar esse gênero musical. Longe de serem meras respostas a uma situação de precariedade e marginalidade no campo da produção cultural, essas dinâmicas se revelam como práticas criativas que atendem a sistemas de valores diferenciados.

Palavras-Chave: Lambadão, Periferia, Cultura Popular, Produção Musical. 


\section{Lambadão:}

\section{breaking the borders of the periphery}

\section{Lidiane Freitas de Barros; Patricia Silva Osório; Juliana Braz Dias}

Sporadic presentations of the musical genre lambadão in the Brazilian media usually carry an image of novelty and exoticism. This was the case on August 30, 2015 when the presenter Regina Casé announced the main attraction of that episode of the nationally broadcast program Esquenta!, on Brazil's leading television network, Rede Globo. With her eyes wide open and an air of suspense, she asked the audience: "Do you know the lambadão genre from Cuiabá?”

Beyond the region known as Baixada Cuiabana, where the musical genre reveals its vivacity, lambadão commonly triggers curiosity: what kind of music and dance are these that seem to have their own trajectory, far from the traditional production and promotional strategies of the Brazilian cultural industry? Lambadão carries the mark of the "periphery" of the Mato Grosso state. It is not isolated, nor definitively separated from the "center". It has flirted in certain times and places, as we will see, with the hegemonic musical production process in the country. But it also demonstrates a defiant autonomy and creativity, which question suppositions about hierarchies and relations of dependency in the field of cultural production.

Phenomenon in the field of "popular culture", such as lambadão, have usually been defined based on their opposition to what is understood as erudite, official or elite culture. ${ }^{1}$ But this does not suppose the existence of parallel and separated cultures. To understand the complexity of this relationship, we need to observe the efforts made in the field of cultural studies, inspired by Gramsci, which present a notion of popular culture as a field where a struggle for hegemony takes place, that is, a space of inter-relationships between dominant and subordinated forces. As Stuart Hall (2003) suggests, popular culture (like high culture) is not an essentialized domain that encompasses a constant content, but is the historic and contingent realization of a structural opposition. Popular culture can only be understood in its relational dimension - like the concept of "periphery", which is based on an opposition to a "center". It is thus a relationship with a potential to be continually altered: what is popular today will not necessarily be popular tomorrow, and can break the frontiers of the periphery.

Another characteristic that is usually indicated by scholars of popular culture is the vitality and potential for inventive freedom in this field. As Johannes Fabian affirms, "popular culture theory asserts the existence of spaces of freedom and creativity in situations of oppression and supposedly passive mass consumption" (Fabian 1998: 2). If at times the scholarly debate about popular culture appears to be depleted, trapped in a conceptual search that advances in circles, the phenomenon that it examines is far from depleted. This article discusses this creativity - in particular, in alternative forms of musical production and promotion.

Lambadão is a product of lower class communities that, without expecting recognition from the cultural industry - but in dialog with it - use their own devices to have their music be heard. Their main strategy is the formation of a network of relations that serves to maintain the productive chain, generating profits, whether through the production of live perfomances or the sale of low cost recordings. In this article we will show that the various dynamics used to produce and promote this musical genre, far from being mere responses to a situation of need, precariousness and marginality in the field of cultural production, reveal creative practices that serve differentiated value systems.

1 See, for example, the discussion by Barber (1987: 12) about the "non official" as a starting point for theorization about popular arts. 


\section{The lambadão genre and the projection of the Baixada Cuiabana}

Innovative musical movements associated to peripheries and based on non-official systems of production and sales have been gaining increasing space in Brazil. Alongside genres such as funk carioca (Rio de Janeiro) and tecnobrega (Pará), lambadão has a production chain that is based on sustainability. Its producers use different dynamics to have their music circulate, such as the organization of concerts, the sale of CDs - which are recorded at live performances or in home studios at low cost - and the distribution of recordings through street vendors, who are important allies in promoting the work of the bands. Not being directly inserted in the mainstream or articulated to the so-called official media - although they establish some isolated interfaces with it - the producers of lambadão create their own market logic.

We use the idea of a non hegemonic system of cultural production. This approach is inspired by rereadings of Gramsci, such as that made by Raymond Williams (1979), based on notions of ideology and hegemony. According to this theoretical proposal, ideology is a form of power maintained directly by the agency of dominant social groups. It involves an articulated system of meanings, values and beliefs associated to a particular class and that attains the level of consciousness, of both the dominant and subordinated classes (Williams 1979: 108-109). Meanwhile, hegemony, which especially interests us here, refers to a particular type of domination, which acts in a more diffuse and less direct manner. It is marked by a complex combination of forces, and is experimented in various spheres of life - including the field of musical production and consumption. It is a kind of power that becomes internalized in the form of conventions and values.

Nevertheless, even if it is always dominant, hegemony is never exclusive (Williams 1979: 115-116). It must respond to a series of pressures exercised by other ("non-hegemonic" or "popular") force fields that limit, alter, and challenge it. Dominant culture is not fixed, nor is popular culture. Both domains can only be defined by the relationship of tension between them. Between dominant and popular culture there will always be points of resistance, acceptance, overcoming, influence, rejection, exchange, opposition, capitulation, incorporation, distortion, and negotiation (Hall 2003: 255-259). Even if there are evident relations of domination and subordination, the productions of popular culture respond to what is imposed on them, and can be altered or eliminated by the dominant culture, but can also modify this dominant culture, or simply endure as an important space of resistance.

It is in this relationship of tension between the dominant culture (which is legitimated by the elite) and the popular culture, produced and consumed by people from the peripheries, that we seek to situate the lambadão genre. Lambadão conforms a non-hegemonic system that dialogs with the hegemonic cultural industry, at times subordinated to it, but always capable of challenging it, creating differentiated and relatively autonomous processes of musical production and distribution, based on original values, within a particular logic of market.

To reflect on the dynamics of lambadão as an industry of popular entertainment or as a type of nonhegemonic system, we begin by sketching an overview of this musical genre. The idea is to present a few historic facts and narratives from musicians about the origin of this genre, identifying some elements that are essential to understanding the place of lambadão in Mato Grosso. We also introduce some data about the representations stated by street vendors, musicians and consumers about lambadão, considering its association with the periphery. These elements are fundamental for sketching a characterization of the cultural expression under scrutiny.

Lambadão is projected and sustained with great strength in the Baixada Cuiabana, a region of Mato Grosso whose geographic limits are the Pantanal to the south and the Chapada dos Guimarães to the northeast. It includes the municipalities along the Cuiabá and Paraguay Rivers and its main center is the state capital, Cuiabá. 
There is a certain consensus among researchers that musicians from the city of Poconé were mainly responsible for the creation of lambadão. This perception is associated to a historic issue, given that this municipality was where lambada (a musical genre that originated in the Caribbean) entered Mato Grosso, and which was one of the ingredients for the formation of the musical style analyzed here. ${ }^{2}$ Researchers also indicate the influence of carimbó music from Pará state, and of rasqueado, a genre that is very common in Mato Grosso (Caldas 2011; Bólico 2011; Rosa 2009).

In conversations with musicians, other perceptions arise to help understand the origins and development of the genre. In addition to lambada, carimbó and rasqueado, new musical practices and new locations are mentioned to compose the diversified landscape in which lambadão is inserted. Many musicians want their own city to be considered the "birthplace" of lambadão. Musicians from Várzea Grande, for example, are certain that lambadão was born in bars and popular festivals of the region in the 1980 s. We thus find a set of competing versions, which tend to emphasize the enunciators of each one of these narratives, in a dispute for being recognized as pioneers and for ownership of lambadão.

We also note that in narratives about the origins of lambadão, other elements are mentioned in an attempt to offer a historic reconstruction of the genre, such as details about technical dimensions. For instance, one of the interlocutors in this study explained that lambadão has progressively replaced rasqueado as the preferred rhythm in popular events. According to this musician, the rasqueado genre required greater motor coordination and physical strength of the musicians. So, to simplify the music, they created the beat of lambadão. The rasqueado rhythm is faster, and since the musicians had to play all night long, they began to reduce the time of the pedals, and rasqueado began to lose force. Moreover, according to this musician, rasqueado was very regionalist and spoke only of the iconography of Cuiabá, not winning the sympathy of the public that lived in the interior of the Mato Grosso state: "lambadão arrived, just like forró, speaking more of love".

These imbrications and junctions became experimentations. Not only through the fusion of styles and techniques, but also because of the bold manner that lambadeiros developed their own market, interacting and maintaining a solid communication with low income communities. These musicians support themselves financially with the cultural market strategies that they developed, without government incentives, in a constant search for ways to make their music viable.

In statements that recall the initial moments of popularization of the lambadão genre in the mid 199os, some musicians emphasize the indifference of the middle and upper classes, who did not see it as a product of Mato Grosso culture. The indifference came especially from people who lived in the capital. By means of practices and discourses related to the consumption of cultural goods, the Cuiabá elite maintained its distance towards the lower classes and their forms of entertainment. The disdain of the elite towards popular manifestations is not particular to Mato Grosso, as Pierre Bourdieu (2006) revealed so well. Yet as seen in similar cases, this posture of the elite can change over time, particularly when a musical genre reaches new contexts, awakening a curiosity beyond the periphery.

In the article "Funk and Carioca Popular Culture", Hermano Vianna offers some considerations about the images of funk and its association to official representations about popular culture from Rio de Janeiro. The author questions the idea of authenticity. Vianna (1990) reveals that a cultural manifestation has different consumer environments for different publics and nevertheless is able to remain independent. In relation to Carioca funk, a musical genre from Rio de Janeiro, its products "can be consumed in different manners by different social groups and can circulate (even internationally) through unconventional routes" (Ibid., 249).

2 According to Caldas (2011), lambada was taken to Mato Grosso by gold diggers who, after an unsuccessful search for gold in Pará, located in Mato Grosso cities such as Rosário Oeste, Várzea Grande and Poconé. 
Similar to the way that funk carioca attained an "official" status, lambadão has gradually conquered its place in Mato Grosso, attracting new audiences, including part of the intellectualized elite who begins to give greater value to the local production, affirming a trend towards the valorization of cultural movements of the peripheries. This has been corroborated by recent monographies from final course projects at the Federal University of Mato Grosso, especially those in the communication school, such as: "Lambadão: a Invenção de um Circuito Cultural e Comunicacional" [Lambadão: the Invention of a Cultural and Communicational Circuit], by Sandra Maria Souza Rosa (2009), and "A Desforra da Periferia" [The Revenge of the Periphery], by Lucas Bólico (2011). Other final course projects include a paper at the Centro Universitário Cândido Rondon, by Dewis Maycon Meneses Caldas (2011), "Vai Descendo Até o Chão, Fazendo 'nhéconhéco' no Salão: a Comunicação das Bandas de Lambadão em Cuiabá e Várzea Grande” [Go Lower to the Ground, Doing "nhéconhéco" in the Hall: the Communication of Lambadão Bands in Cuiabá and Várzea Grande]. At the master's level, we can mention two dissertations defended in the graduate program of contemporary cultural studies at the Federal University of Mato Grosso: "O Lambadão de Mato Grosso: Registros de uma Dança Popular Urbana" [Lambadão of Mato Grosso: Registers of a Popular Urban Dance], by Tânia Fontes (2012), and "A cadeia produtiva do lambadão: rompendo as fronteiras da periferia" [The Lambadão Production Chain: breaking the borders of the periphery], by Lidiane de Barros (2013).

Many of the lambadeiros believe that the "capital of lambadão" is Várzea Grande, since most of the active bands and their musicians come from this city. Yet some have told us that there is a lack of recognition from Cuiabá, the state capital, regardless of the fact that the two cities are separated only by a river. "There are some places in the capital that do not recognize lambadão as regional culture", one of our interlocutors declared. Nevertheless, the growth of its popularity is notable, even if it has not reached wealthier regions of the state capital as lambadeiros would like to.

In response, one of the methods explored by its protagonists has been to use virtual spaces such as specialized music sites or social networks such as YouTube. In the 199os, the reality was different, given that the internet was still not used as a tool in the promotion of lambadão and the work of the bands was only accessible through sales by street vendors. One musician recalls that the indifference of some people was also related to the genre's bad reputation. He recalls that critics of the style thought that the lambadão dance - marked by very fast and sensual steps, with movements in which the hips of dancers would touch was too explicitly erotic, which impeded the acceptance.

This dimension is reinforced by the words to the songs. Lambadão lyrics touch on various themes, many of them associated to romantic relationships: "I'm crazy about you/ If you want to come back to me/ This time it will be my way/ I'm crazy for you/ Give it a try and see if it changes" - an excerpt from the song "Sou louco por você" [I'm crazy about you], by the band Scort Som. Although they deal with various themes, many of the songs are erotic. The song "Pica Pau", by the band Erre Som, was inspired by a children's cartoon character. ${ }^{3}$ The lyrics have an ambiguous meaning with an erotic provocation: "Here comes the woodpecker/He likes to peck/ When he is flying/ he is always pecking/ He likes to peck/ The woodpecker is coming/Everyone is watching/ He draws attention/ His head is red/ He is very beautiful/ His laugh does not lie".

Lambadão songs and dancing motivate pejorative analyses about the genre. In 1997, one of the pioneer bands, Estrela Dalva, was invited by the host of a nationally popular daily variety show, Ratinho, who had seen them at a political rally, to participate in his program. The TV host made many pejorative comments about the lyrics and dance style. This left the musicians and public upset. During the study that led to this article, the episode was mentioned by various interlocutors. One musical producer recalled: "The program's

3 The cartoon character is Woody Woodpecker. "Pica Pau" means woodpecker in Portuguese, while "pau” is slang for "penis". 
staff were not professional. They invited the band for a ridiculous segment, without even speaking with the musicians to warn them about how they would treat the novelty, given that the lambadão genre, still restricted to the state [of Mato Grosso], began to be promoted nationally". One musician also mentioned the televised incident and criticized what he considered a "lack of respect for the lambadão musical movement”. In his words, “Estrela Dalva's appearance on Ratinho was one of the most negative points for the lambadão genre and until today is polemical. Because of the type of dance. But it is very easy to discriminate. The elite do not like it, but at carnival, women can go topless!".

Nevertheless, lambadão made another national appearance, which lambadeiros consider dignified. The brothers Ronildo, Ronaldinho and Ronny, who form the band Erre Som, reported that in 2005 they were invited to participate in the segment "Central da Periferia" [Central Periphery], on a nationally broadcast show of the Globo TV network, Fantástico. Regina Casé, a national star and host of the program, came to Cuiabá just to interview the trio. Moreover, in 2015 she turned the spotlight on the Mato Grosso genre once again on the program Esquenta!, as reported in the opening of this article.

Another conquest of the lambadão genre is a more recent flirtation between the periphery and the wealthier economic classes of Mato Grosso. In July 2012, the band Scort Som was cheered at the festival Feijoada de Inverno de Chapada dos Guimarães, an annual event that attracts wealthy people. The band returned to perform at later editions of the Feijoada de Inverno and was also invited to a segment of the program É Bem Mato Grosso, on TV Centro América, the regional affiliate of the national Rede Globo TV network, where it performed its music on various segments and told its history. It is important to highlight that this television program, presented on Saturday afternoons, focuses on Mato Grosso culture. The program reports on traditional festivals, various popular manifestations, such as the cururu and siriri, ${ }^{4}$ and presents regional artistic talents including painters, artisans and musicians. The program is presented by Pescuma, a regionally well known musician thanks to his performance of rasqueado and who at times conducts projects with the Orchestra of the Mato Grosso state, like the recording of the DVD Cantos do Brasil, with a repertoire permeated by popular music. The name of the program is a direct reference to one of his compositions, "É Bem Mato Grosso" [It is really Mato Grosso], a song that praises the regional landscape and culture.

Despite the apparent growing appreciation of lambadão - largely as it is seen as a spectacle because of its irreverence - and the fact that its agents are trying to articulate themselves and perform more regularly, the genre acceptance does not seem to be consistent. According to one of the musicians, there is a notable lack of spaces to play in Cuiabá:

There is this problem here, there are no venues for lambadão. The Praça do Lambadão, in the neighborhood of Bela Vista, closed. Erre Som tried, but did not make it, it could not go on. We suffer a lot of discrimination from government. We conducted the project "Praça do Lambadão" for the first time in 2007. At the time there was rasqueado downtown, and lambadão here in the Planalto [neighborhood]. We won incentives and every Friday for four months we had money. There would be an average of two thousand people a day. Two bands, every Friday. It ended at a fixed time. The musicians were paid. Only musicians who we could pay performed, although there were people who wanted to play for free. We tried to professionalize the concerts, we hired security. So we were able to ideate the project, but today it is hard to organize an event. The police shows up, the environmental agency [SEMA - Secretaria de Estado do Meio Ambiente] stops everything. It's a fight for which we are preparing, with legal support. We will fight with the city government, with the state attorney general, who is linked to those who want to defeat lambadão.

4 Cururu and siriri are popular musical genres (and dance styles) that can be found in the Mato Grosso state, performed on percussive and string instruments. Such manifestations are present in festivals celebrated in homage to catholic saints. They are considered to be legitimate examples of local tradition. 
The lambadão genre is consumed as entertainment in the periphery, and takes on the character of a bold attraction when it is consumed among the elite. The musicians begin to perceive a small change in how the elite sees the lambadão because of invitations they have received to play, and even if it is not with the seriousness that they would like to be treated, in a certain way, they try to be optimistic and credit this projection to the festive character of the genre.

The image of lambadão appears to aggregate an irreverent and playful quality to events of the elite. The music is still seen as exotic, which is the reason for hiring a band. One interlocutor for the study reported that his band was invited to a "very elegant party", the wedding of a businessman, owner of a sophisticated restaurant in the capital. The host requested that the band not announce their presentation at his wedding on the band's website. He wanted it to be a surprise for the guests, who would certainly get quickly involved when lambadão began to be played. "They [the rich] always dance. When its time to say that they like it, they won't admit it, but when the music plays, they begin to dance right away; if they are a bit 'high' then... there they go".

These episodes, reported during the interviews conducted with the musicians, reveal how, despite the stereotype and the struggle to conquer space in the capital and in Várzea Grande, the lambadão genre proliferates in Greater Cuiabá. A complex process is observed, which does not allow for simplistic dichotomies. Lambadão resists the criticisms and the pejorative images presented by the elite in certain contexts. It is promoted, even without support from the media and government. But its producers know very well how to take advantage of the gaps that open from time to time, whether at local events with a special public, or in the realm of the hegemonic cultural industry. And the same elite that at times looks down on lambadão, at other times adopts it or simply lets itself be influenced by the cultural effervescence that comes from the periphery. In this field of hegemonic and non-hegemonic forces, the diversity of possible relations is very important to consider.

In the interviews with the producers of lambadão, what we saw in general was their concern about being respected. And one of the reasons for the persistence and proliferation of the lambadão genre, even in unfavorable situations, is its particular forms of production. This non-hegemonic system of production and promotion allows the maintenance of this cultural expression and its viability as a source of income for the agents involved in it. Lambadão is a representative of new models of cultural production that are emerging in the peripheries - or in the backyards, as in the case addressed in this article.

\section{Production, diffusion and consumption of lambadão}

After providing a panorama of the lambadão genre, its origins and images, we will analyze its production, diffusion and consumption. Certain mechanisms will be highlighted, particularly the shift from professional recording studios to recordings in home studios and during live performances, and the rampant distribution of recordings by street vendors.

Concerts are the main instrument for generating income and support for the lambadão musicians and their families, and also provide a financial "reinforcement" in the life of street vendors who work during the performances. Most of the concerts are held at music halls or parking lots that are built in backyards by people who see an opportunity in these open businesses - the horizontalization of production is conducted in network. The expansion of the number of spaces for the concerts entails involvement of various agents. 
These include the stage crew and operators of sound and lighting, equipments and venue owners, those who do the filming, as well as people not directly involved with the musical production, such as street vendors who work during lambadão events. ${ }^{5}$

The promoters of lambadão also reinvent themselves by improvising and using labor obtained from interpersonal relations. In the region of Várzea Grande, homes on large lots had ground paved and quickly served as the base for concert spaces, at times covered by roofs of straw or asbestos tiles. The house of the manager of the band Scort Som, for example, became the Residência do Seu Gonçalo, known for live music performances. The informal character and domesticity appear to be intrinsic to the cultural market that has developed around the lambadão genre. On days of lambadão concerts, the family routine changes, given that friends and family of musicians and organizers of the concerts perform various functions in a division of tasks, from cleaning the location to attending clients. Moreover, many homes of lambadeiros that are not used for live performances may be used instead as recording studios and rehearsal spaces, as is the home of the musicians from the bands Os Ciganos and Erre Som.

We play a lot in the backyards. The yards have no structure, while the legal spaces have licenses, authorization from the city, the fire department; Galpão, Cabana and Big Chopp [concerts venues] have all the documentation they need. The venue De Paula is closed because the owner invested, but the public, with no explanation, stopped going there. The house "burned", there is no logical explanation. Keeping a house functioning for a number of years is difficult and that is how the owners of the yards do well, because they do not need to spend on the licenses.

What interests us in this statement is the differentiation between "legalized" houses and "yards". The legalized venues are the formalized ones, with operating licenses, that follow the laws concerning safety, sanitation and taxes. They are the places with licenses. While the yards are spaces functioning outside of this logic. They are places that are often improvised in the domestic area of the owner. It is an informal business that involves family members and friends. The statement above emphasizes that many of the lambadeiros play in the backyards. Some owners invest to become legalized. However, "without explanation" the public may stop going to their venues. This point suggests that the lambadão genre is organized in informal chains of operation - in contrast to an official circuit with "documentation" - and inserts itself in the logic of the "backyards".

In addition to the venues already mentioned, there is also the Clube do Zé Pimenta, the Cabana da Dudu, Globo Show, Laço de Ouro, Central Bar and Galpão. In Cuiabá, we may include Salão de Benedito, Mangueiral, Top Fest, A Baianinha, Salão do Baianinho, Retirão and Reserva Restaurante. These venues are mainly located in the neighborhoods of Tancredo Neves, CPA III, Dom Aquino, Campo Velho, Tijucal, Planalto and in the urban perimeter along state highway MT 251, which leads to the Chapada dos Guimarães. Two important points must be highlighted. The first refers to the denomination of these locations. Many of them mention the name or nickname of the owner: Cabana da Dudu [Dudu's Shelter], Salão de Benedito [Benedito's Hall], Clube do Zé Pimenta [Zé Pimenta's Club], Salão do Baianinho [Baianinho's Hall], etc. The names reveal the domestic character of the lambadão genre. The other point to be emphasized is that all of these locations are relatively far from the city center and wealthier neighborhoods; they are in peripheral neighborhoods associated to the poor and working classes.

5 Lucas Bólico noted this issue in his study about lambadão, emphasizing that the resources that circulate in live performances involve not only the musicians or promoters of the event: "Around an event related to the genre in the periphery, there are countless people looking for an extra something. They are people who sell food and drink in the street, people who watch cars, neighbors who open garages outside their houses and people who enter the dance with authorization of the owner, also to make some money" (Bólico 2011: 66). 
To complement the discussion about the importance of the backyards in the production of lambadão, we refer to the promotional strategies for the concerts. The main forms of promotion reveal the dimension of improvisation and use of alternative strategies to attract the audience, based on informal models. One of these mechanisms is hunging banners in specific neighborhoods. The promotional methods are made even more complex because people who attend concerts in backyards and also in legalized houses are attracted not only by the certainty that they will have fun, but because they were "prepared" before hand. They are in constant contact with lambadão music, given that there is nearly unrestricted access to the recordings - which can be heard at family parties, in cars, or purchased at shops and stands that sell pirated CDs and DVDs. Musical productions are offered on a large scale at low prices by street vendors, to the extent that performers do not have control of how many copies are made. They benefit from this form of musical promotion, because becoming popular makes it certain that they will be hired to perform at concerts - the main source of income.

We highlight that this is not, in fact, an exclusive characteristic of lambadão. In relation to the music market, in a wide variety of contexts worldwide, there has often been a shift of profits from the sale of recorded music to the sale of admission to concerts. Contrary to the more pessimistic perspectives about the technical reproducibility of music, inspired by the classic work of Walter Benjamin (1973), the digital revolution has positively influenced musical performances, whether in grand spectacles or at smaller concerts, in restricted spaces. The direct experience with live music has been revalued, coming to be the most important source of income in the music market (Braz Dias 2014).

Therefore, it is necessary to relate the lambadão genre to a broader discussion about the music market in the digital era - including both the most alternative and peripheral systems of production and distribution as well as those engendered by the entertainment industry, in the domain usually called mainstream. With the drop in CD prices, even internationally famous musicians who work with large recording studios view recordings more as a way to attract fans to their concerts, where more income is possible. The journalist Robert Sandall (2007) presented a curious calculation: "You could have bought Madonna's entire catalogue for less than half what it cost to see her perform at Wembley Arena”. Recordings have been reduced to the role of a mere form of advertising.

Analyzing the digitalization of the Brazilian recording industry, Wainer $(2016 ; 2017)$ reinforces the argument about this diffuse effect of new digital technologies. As this author demonstrates, what in the late 1990 os was experienced as a crisis by the Brazilian musical market, associated to the proliferation of pirating of $\mathrm{CDs}$ and sharing of $\mathrm{MP}_{3}$ files, has now revealed interesting facets. One of them is the process of decentralization of musical production. The new configuration of the music market at the turn of the century allowed the rise of cases like that of the emblematic group Calypso. Coming from Belém, in northern Brazil and at the margins of the recording market located in central and southern regions of the country, Calypso grew through the use of digital technologies in an autonomous economic circuit outside the mainstream recording productions - although it took advantage of this later on. Independent routes became possible, as is the case presented in this article. Even if we refer to a "specific" market for lambadão, it is not separated from this broader context.

Returning to the situation under scrutiny, professional studios are still inaccessible to most lambadeiros. One musical producer in Cuiabá, the owner of one of the best studios in the region, explained that many of the lambadão recordings originated from the recording of live performances. The recording is done on laptop computers, which does not guarantee good sound quality, according to the criteria of other musical fields. When the bands decide to invest in professional studios, they do what is necessary to reduce costs, as our interlocutor explained: 
For example, the recordings are made with the entire band at the same time and they do not pay for extra musicians or for the arrangements, and much less, have a musical producer. At least, in my studio, they never use them. Except for a recording of the track "Judiação" in partnership with the sertanejo musicians João Carreiro and Capataz.

It is important to discuss in greater detail about the "quality" of the production process. We note that what can be interpreted as a lack of care, precariousness and improvisation deserves another interpretation. Considerations about quality only make sense if we have a certain desired standard as a reference. When the final objective is the purity of the sound, a live recording made with a simple laptop computer does not seem to be suitable. But, if the emphasis is on fast promotion and low costs, these strategies may not be seen as precarious and inadequate.

Another example deserves to be mentioned. One of the studios used for lambadão recording is a room in the home of one of the musicians, an interlocutor in this study. The location is simple, with no acoustic insulation. There is only a computer that is equipped to capture the music. There was a time when the room had acoustic insulation. But the owners decided to remove it to create a more pleasant and well-ventilated space. The walls were painted green to make it more hospitable. We note that other values are involved, different from a priority concern for the quality of the sound. A space suitable for sociability can be an important objective, associated to the always present concern of having the music circulate, making the music known.

Concerts are largely promoted through unlimited distribution of CDs copied by street vendors, and sold at a low cost. In addition, banners and posters are hung and sound trucks circulate in the streets. At times there is advertising on TV and radio. Those who perform in Greater Cuiabá may also receive promotion on community radio programs and on the TV Lambadão Show, which began in July 2013.

Today some artists use the power of the internet to promote their songs. However, there are still few groups that share their music online. Most of them have not explored the potential of the web for promoting concerts, even on music sites. Posters, banners, "mouth-to-mouth" and sound trucks are the main channels for promoting events.

Some of the people we interviewed indicated that they are looking for specialists to conduct online promotion because they are not familiar with the internet - which questions the acclaimed democracy of access to the virtual world promoted in the specialized literature. It is important to emphasize the life trajectory of many of the people involved with lambadão. Many of the band members have not completed high school and work in construction or at gas stations. ${ }^{6}$

Even if there are still only a few who invest in digital marketing, the lambadão genre advances on the global internet given that fans often use YouTube channels or sites with music, lyrics and videos - such as MySpace and PalcoMP3 - to promote entire CDs by lambadão groups. This is how lambadão crosses borders and becomes called by new names. In Brazil's Northeast, it is known as the forró Cuiabano. The lambadão genre, which has variations such as the lambadinha, ${ }^{7}$ has also won fans in neighboring countries, such as Bolivia and Paraguay. It has even gone much farther. Members of the band Scort Som say that lambadão can be heard in Japan, Greece and Portugal, promoted voluntarily by friends who live in these locations.

Jukeboxes found in bars in the periphery often play recordings by the better known lambadão groups. The bands are not highly concerned with the recording processes, as mentioned, except if they need to remove some interfering elements from live recordings. But they do not turn to musical producers to do so, which limits the presence of these professionals in the creation process. They make the recordings themselves, sell them at concerts and count on street vendors to make new copies.

6 There is a case, in particular, of a musician and member of a band that is well known and who has a law degree and a political career. He has worked mostly as a broker, mediating relations between the universe of lambadão and other sociocultural domains. 
The vocalist from one of the bands said that he knows of at least $49 \mathrm{CDs}$ that were recorded while they played at various lambadão "houses". "While we play, there is someone with a notebook turned on and recording, and they sell them right there". Since street vendors have complete control over the recordings when they are released, with freedom to reproduce them, they also intervene in the covers of the CDs. For example, vendors replace the photos of the band with images of semi-naked women (Figure 1 and 2). And the musicians do not mind: "The vendors promote our work which allows our music to reach various places in the state, especially at the borders with Bolivia and Paraguay". While professional musical producers are excluded from the lambadão production chain, street vendors are an important part of this creative process.

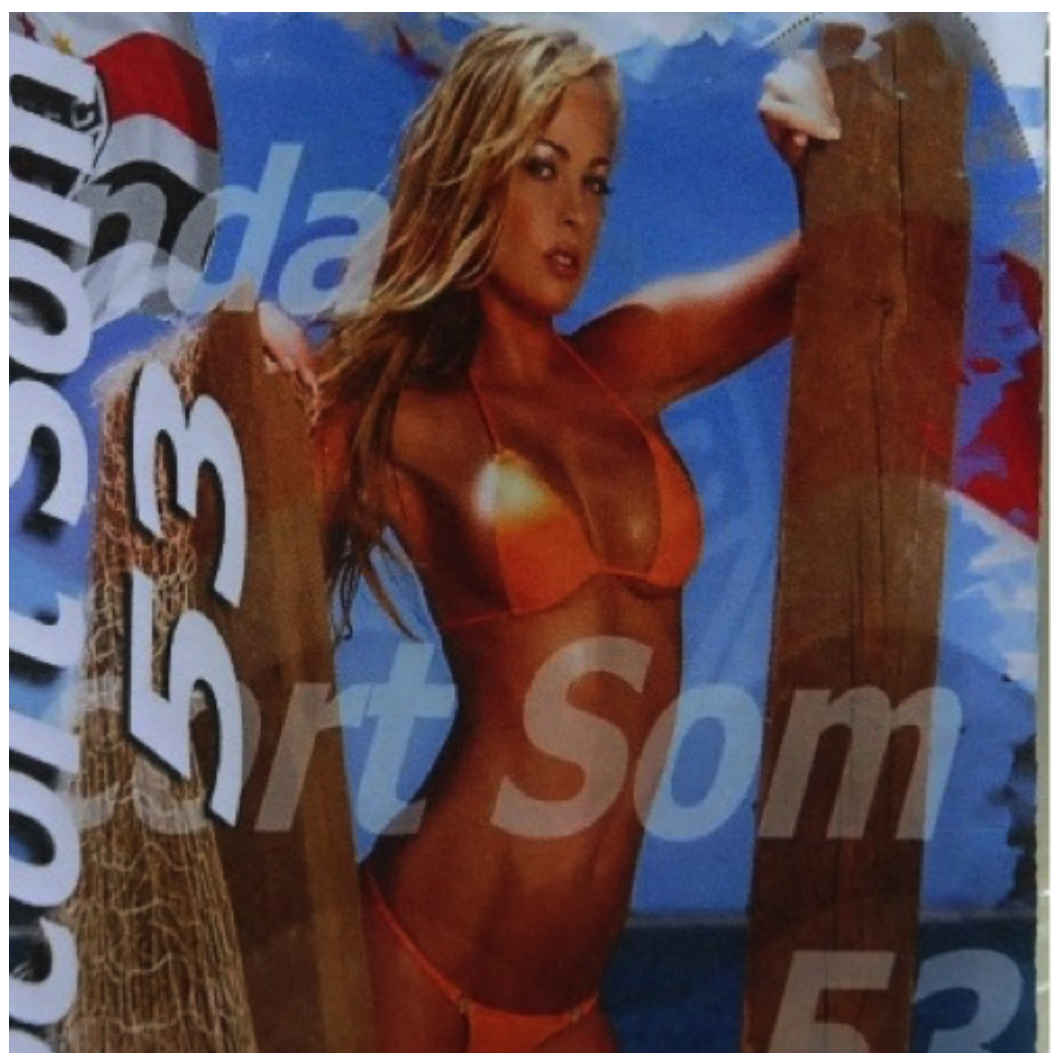

Figure 1.Cover of lambadão CD from the band Scort Som purchased at a street vendor's stand. The $\mathrm{CD}$ had an "intervention" from the reproducers of the $\mathrm{CDs}$ and the number 53 on the cover indicates the number of reproductions of the recording. 


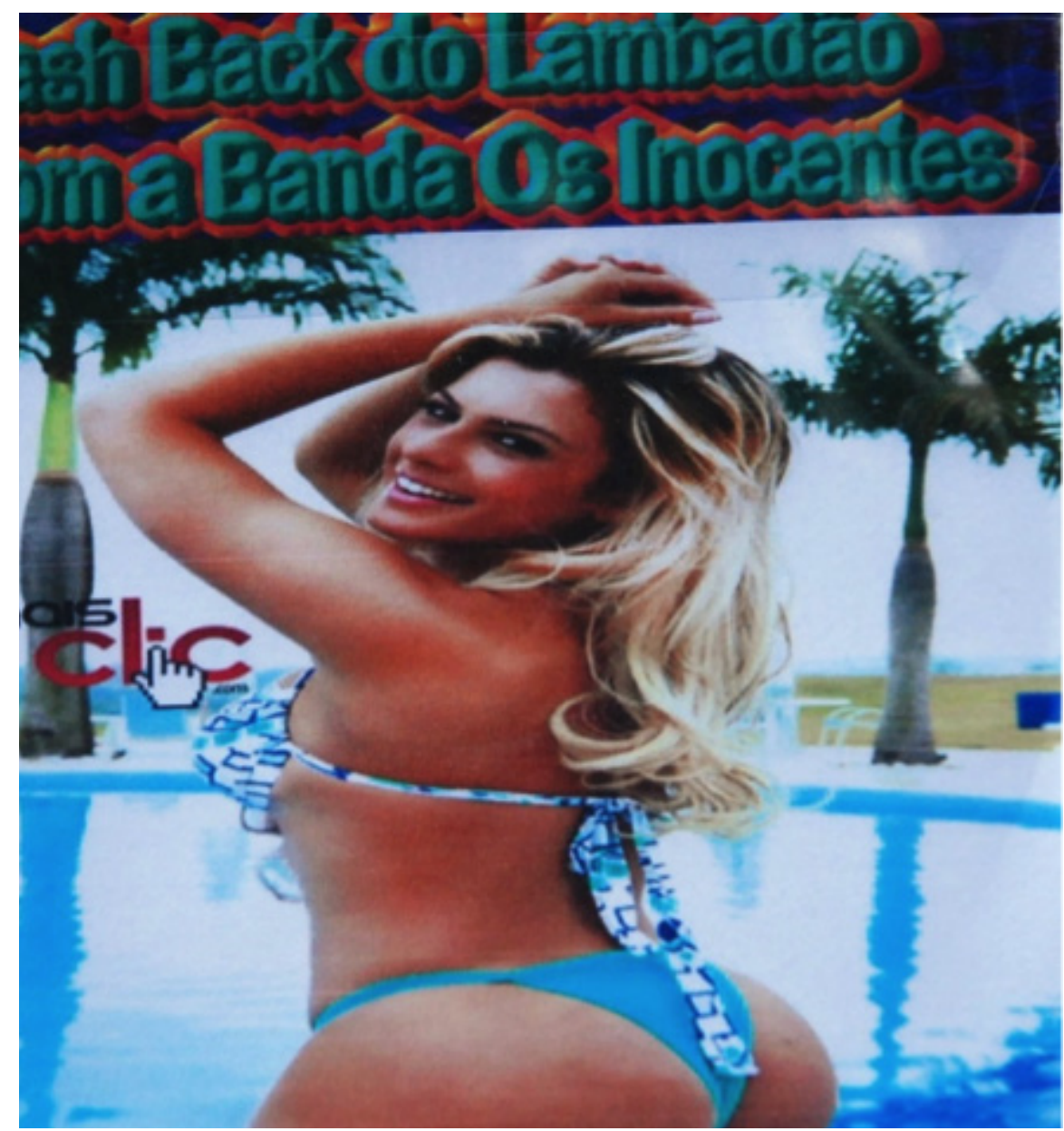

Figure 2. Cover of $\mathrm{CD}$ from the band Os Inocentes. We may note the watermark on the image that identifies the website where the photo was found.

In the early 1990s, the copies were not made on CDs. This technology only became accessible in the decade of 200o. Before then, lambadão circulated on cassette tapes. One musician recalled a pioneer use of the $\mathrm{CD}$ :

A friend said that the owner of a store had a device for reproduction and we said that we wanted to record. Our income was very small. So, it all began with the Stilus Pop Som that recorded the CD in a studio and it fell into pirating. In 1999, of every ten songs played on car stereos, nine were from Stilus. We found out that a guy close to home here did recordings with a digital audio deck, but it was very expensive. Until we thought of a proposal. We asked his son: "When your father goes out, bring the deck to my house, we'll record and give you some money", which was much cheaper of course. That was in 2000. At that time the bands recorded CDs to play on the radio, they did not make copies and did not sell them. Knowing a guy who dominated the pirating, I made a private copy, a master.

With the recording in hands, he went to a street vendor in the city working on the sale of records and asked him to "hack" the CD. But the vendor wasn't interested, he said he was wary of making copies of regional music, even if the author himself was asking. That's when they made the copies and took them to sales points. 
But since he did not want to reproduce it, we did it ourselves. The following week, we decided to make 100 copies and took them to him. In a week he sold everything. It was pirating that allowed us to make our dream come true and we now have nine recordings, all released from the start by street vendors. We never went to a professional studio. So we spent an average of $\mathrm{R} \$ 80$ to $\mathrm{R} \$ 100$ [approximately US $\$ 25$ to US $\$ 30$ ] to buy the disks. They were so successful that in one weekend we went to play in the interior and we earned what we never earned in a month. We kept feeding the vendors every week and never knew how much our band sold, because, after all, our profit comes from concerts. At a concert, if we are not involved with ticket sales, we charge a participation fee. In reality, its as if we pirate ourselves.

The lambadeiros, in addition to producing independent and low cost recordings, need to make the material available to the economically disadvantaged population, whether at street fairs or in low income shopping districts. These strategies were used by two exponents of tecnobrega, Gaby Amarantos and Calypso (Lemos and Castro 2008). At the beginning of its career the band Calypso, mentioned above, made recordings sold at low prices. But later they created their own studio and sold recordings in supermarkets. The projection was more consolidated when the band began to travel throughout Brazil doing concerts in peripheries. Later came recognition from the major media: presentations on the nationally broadcast and famous Sunday afternoon variety program Domingão do Faustão on Rede Globo, and appeared on the cover of the Brazilian edition of Rolling Stone magazine. What we want to highlight with these approximations is that both tecnobrega and lambadão have a production chain that is supported by the "metamedias", a concept coined by Amaral (2009: 16). These are alternative or non-conventional media, like pirate CDs sold freely in the city and even virtual audio editors downloaded for free on the internet by musical producers. The peripheries use new technologies, to which they attribute new uses, to strengthen their strategies and networks. As the author affirms, "the artists do not earn money from the sale of CDs, but with the concerts that they perform and earn them more than they would earn by collecting authorial rights" (Ibid.: 37).

Lambadão recordings are sold at low prices. At stands that sell pirated CDs in Mato Grosso, two CDs may cost R $\$ 5$ [less than US\$2]. If recording was done with major studios, this would not be possible, given that in this process the prices are determined by production, promotion and sales costs, which increase the cost of the CDs. In an interview conducted with a member of a band, he said that he used to give thanks to God and to the street vendors who circulated his material.

The data just presented inspire us to conduct a theoretical review of the concept of "pirating". Following other authors who have discussed different meanings of "copying" (Pinheiro-Machado 2012; Ribeiro 2013), we suggest a removal of this practice from the realm of illegality - at least as a universal criteria. Although pirating is framed as a crime in certain contexts, in others, copying is a highly valuable practice.

The negative image of the copy, specifically in the domain of music, is part of a powerful ideology, but is not absolute. Walter Benjamin's critique, written in 1936, is the basis of one of the best known arguments against the reproduction of works of art. According to the author, "[e]ven the most perfect reproduction of a work of art is lacking in one element: its presence in time and space, its unique existence at the place where it happens to be" (Benjamin 1973: 222). This absence of the "aura" of the work of art - of the space-time identity of the original - has been, since then, evaluated to be the result of an impoverishing process. It is an argument based on the idea of "authenticity" as a fundamental value. This discourse must be understood, however, as located in a specific socio-cultural context. Anthropologists have introduced various ethnographic cases that show explicit contrasts with this ideology. Tatiana Bacal, for example, in studies about electronic music, presents a type of musical creation in which the procedures of recycling/ bricolage are central, so that the "theft", the "expropriation" of the original work, arise as a new way of making art (Bacal 2012: 112). 
Lambadeiros also relate to the concepts of copy, authenticity and intellectual property in a very particular way. In the context of the lambadão genre, the "consecration" of authenticity as a positive valorization of the original has little importance. Bands hand deliver a master recording to street vendors. The destination and the phonographic quality of the copies are not a priority given that they will be played at times of leisure and fun. This whole music scene is related to pirating, as one lambadão musician highlighted: "If you go around the periphery on the weekend, you will hear how it [lambadão] is playing in homes. They are pirate CDs. There are very few original recordings".

For producers of lambadão, copies help perpetuate the diffusion of their music. The reproductions expand the reach of the genre. Copies propagate lambadão and give the bands visibility. This guarantees the survival of lambadão. The authors do not have their authorship denied by using a flexible model, which helps to legitimate their art.

The idea of authenticity (or its absence) in recordings has little influence on the issue of the legitimacy of the artist. After all, the authorship of the recording is a source of unquestionable authenticity. Replicas thus become "authentic" in a universe of artistic production in which the practice of recordings reproduction is not considered falsification or criminal adulteration. In the case of lambadão, the strategy used to circulate the copies helps the music to proliferate based on a collaborative effort involving various agents. Copies of lambadão recordings do not annul any authenticity; they are a source of innovation.

It is important to evaluate the general conditions of production, circulation and consumption of the sectors involved. The agents, mainly musicians and street vendors, legitimate the economic transactions made in these new forms, based on a new system of priorities, to maximize profit and give continuity to this cultural movement.

Pirating has a subversive potential that [...] touches one of the hard cores of capitalism, at the same time that it contradictorily intermixes with it, given that it combines with the very needs of consumption, of (re)production of social identities, and of distinction under the aegis of electronic-computer capitalism. The structural impulse from contemporary reproductive technologies and from the increased ability to communicate and travel to distinct spaces leads us to believe that popular globalization will proceed, and heterodoxically consolidate and tighten the connections between the various links in the non-hegemonic global system (Ribeiro 2010: 35-36).

The reproduction of $\mathrm{CDs}$ conducted by street vendors with the authorization and encouragement of musicians, according to a non-hegemonic system of musical production, reflects a dual process of technical transformations and transformations in the domain of values.

In fact, technological transformations, which deeply alter both the processes of audio production stricto sensu, as well as the processes of production of material supports for songs and circulation and consumption of music, question in some extreme cases the very representations about artistic creation that constitute the doctrinaire foundation of the particular form of remuneration of the musical workers by the cultural industries, which is the authorial right and or the right linked to the rights of the author. [...] These transformations made economically viable the production of supports by the artists themselves and the circulation and consumption of music without any support from the internet, at the same time that they shifted the recording industry from the central place that it occupied in the music business in the 1970s, destabilizing the division of labor between the artists and those who economically exploited their work, upon which was based the very hierarchy between the "prestigious" artists and the "commercial" artists that symbolically organized the practice and conceptions of the phonographic industry and music criticism at that time (Morelli 2009: 9-10). 
If in popular music of the 1970s, as Morelli explains, there was a clear separation between the process of artistic creation and final production of a recording, this is not true in the case of lambadão. The artists are increasingly closer to their public and do not have the entire apparatus of production and promotion that was the responsibility of the recording companies. The distribution of records is conducted by street vendors who reproduce as many copies as they want and distribute them in the locations where they work. They can also assume a creative function, interfering in the artistic production by substituting the original cover suggested by the performers, for others that they find more attractive. They often use pictures of beautiful women that seem to be taken from the internet, without observing copyrights to the image, or even removing the watermark of the original website.

When the phonographic industry system ruled, the authors and performers were remunerated according to a percentage of the sales of records, and performers were hired and received payments for the recordings that they made. In the so-called official system, musicians are not complete owners of their artistic productions, given that they are only those who "authorize a certain use of this product in exchange for a percentage participation in the sales of the new products that arise from that use" (Morelli 2009: 117). And because of the entire recording industry apparatus, the artist was "protected" by copyrights, which "arose as a legal guarantee of remuneration for artistic work at the same time as arose a specifically modern or capitalist form of exploitation of the works resulting from this work" (Ibid.: 128).

However, lambadão is not a cultural production protected by copyrights. The authors of lambadão songs do not "suffer" from having their works pirated. They need this type of promotion. As we argued, they are benefited by the informal distribution market for recordings; after all, musicians are interested in the money they earn at concerts. Earning from the sales of recordings at concerts serves to cover the cost of production. With the amount they earn monthly with concerts, they can cover living expenses of entire families. Normally, all family members are included in the artistic life of the lambadeiros.

The environment in which the lambadão genre is articulated and projected reveals the existence of business deals within business deals, in which the concept of sustainability is reinforced in the search for financial maintenance and profit, conquered thanks to low cost productions. These businesses strengthen the circuit as a whole. Backyards become concert venues, changing the domestic routine. Families and friends adhere to the activities, using their yards for parking cars, while other people sell food and beverages at the door of their houses.

Both street vendors, who earn money by selling lambadão CDs and DVDs, and musicians, who are able to schedule concerts because of this type of promotion of their work, are fundamental parts of this music movement. In addition to authorizing the copy of their artistic production in a clear disdain for intellectual property rules, musicians practice self-pirating, by giving their work to street vendors. The artists, the creators of the music, will not know how much vendors earn from sales or how many copies they make. Nevertheless, CDs are business cards. Their intense circulation is a sign of prestige, and a busy schedule of concerts is the thermometer of success. Street vendors earn per copy sold and musicians earn for concerts performed, given the promotion attained from the diffusion of copies to a high number of consumers. This relationship creates a collaborative network. Even if the logic of the so-called official market sees pirating as harmful and criminal, it is crucial to analyze how the use of this resource delineates social relations in the context of lambadão.

The practice of reproduction and distribution of copies of live performances is one of the most important items to be emphasized in the entire production process analyzed in this article. By producing the work at low cost and giving up their authorial rights, the agents of lambadão shift the gears of the movement according to a system of informal and sustainable commerce, which is guided by its own rules. 
At the margin of the mainstream, lambadeiros - even if far from the attention of the mass media (with some isolated exceptions) - seek to expand their space and contacts with lower income classes. The search for spaces and the use of pirating are decisive to the consolidation of lambadão.

Finally, it is important to remember that although it is experienced more intensely by people in a nonhegemonic system, the lambadão genre has also conquered insertion in other niches. As we saw, at times it approximates the elite and middle classes, appearing as an attraction on radio and television programs with large audiences or at specific events. Considering as points of comparison the cases of tecnobrega and funk, which are now strongly diffused on the Brazilian pop music scene, it is possible that in the future the lambadão genre will also come to have another relationship with the hegemonic music industry, characterizing one more step of the highly dynamic process that we sought to analyze.

Translated by Jeffrey Hoff

Received: December 31, 2016; Approved: June 12, 2017

\section{References}

AMARAL, Paulo M. G. 2009. Estigma e cosmopolitismo na constituição de uma música popular urbana de periferia: etnografia da produção do tecnobrega em Belém do Pará. Tese de Doutorado, Universidade do Rio Grande do Sul.

BACAL, Tatiana. 2012. Música, máquinas e humanos: os Djs no cenário da música eletrônica. Rio de Janeiro: Apicuri.

BARBER, Karin. 1987. "Popular arts in Africa”. African Studies Review, 30(3): 1-78.

BARROS, Lidiane F. 2013. A cadeia produtiva do lambadão: rompendo as fronteiras da periferia. Dissertação de Mestrado, Universidade Federal de Mato Grosso.

BENJAMIN, Walter. 1973. "The work of art in the age of mechanical reproduction”. In: Hannah Arendt (ed.), Illuminations. Londres: Fontana Press. pp. 219-253.

BÓLICO, Lucas. 2011. A desforra da periferia. Trabalho de Conclusão de Curso, Universidade Federal de Mato Grosso. Mimeo.

BOURDIEU, Pierre. 2006. A distinção: crítica social do julgamento. Porto Alegre: Editora Zouk.

BRAZ DIAS, Juliana. 2014. "Música e experiência na era da reprodução digital”. Anuário Antropológico, 39(1): 219-240.

CALDAS, Dewis M. M. 2011. Vai descendo até o chão, fazendo "nhéconhéco" no salão: a comunicação das bandas de lambadão em Cuiabá e Várzea Grande. Trabalho de Conclusão de Curso, Centro Universitário Cândido Rondon. Mimeo.

FABIAN, Johannes. 1998. Moments of freedom: anthropology and popular culture. Charlottesville: University Press of Virginia.

FONTES, Tânia. 2012. O lambadão de Mato Grosso: registros de uma dança popular urbana. Dissertação de Mestrado, Universidade Federal de Mato Grosso.

HALL, Stuart. 2003. Da diáspora: identidades e mediações culturais. Belo Horizonte: UFMG; Brasília: UNESCO. 
LEMOS, Ronaldo; CASTRO, Oona. 2008. Tecnobrega: o Pará reinventando o negócio da música. Rio de Janeiro: Aeroplano.

MORELLI, Rita. 2009. Indústria fonográfica: um estudo antropológico. São Paulo: Editora Unicamp.

PINHEIRO-MACHADO, Rosana. 2012. "Mona Lisa made in China: refletindo sobre a cópia e propriedade intelectual na sociedade chinesa a partir do caso de Dafen". Proa - Revista de Antropologia e Arte, 1(3): 01-15.

RIBEIRO, Gustavo L. 2010. "A globalização popular e o sistema mundial não hegemônico". Revista Brasileira de Ciências Sociais, 25(74): 21-38. . 2013. "What's in a copy?". Vibrant - Virtual Brazilian Anthropology, 10(1): 20-39.

ROSA, Sandra M. S. 2009. Lambadão: a invenção de um circuito cultural e comunicacional. Trabalho de Conclusão de Curso, Universidade Federal de Mato Grosso. Mimeo.

SANDALL, Robert. 2007. "The day the music industry died". The Sunday Times, Londres, 7 de outubro de 2007. Disponível em: http://entertainment.timesonline. co.uk/tol/arts_and_entertainment/music/ article2602597.ece. Acesso em: 7/07/2011.

VIANNA, Hermano. 1990. "Funk e cultura popular carioca". Estudos Históricos, 3(6): 244-253. . 1988. O mundo funk carioca. Rio de Janeiro: Jorge Zahar Editor Ltda.

WAINER, Daniel F. 2016. Trajetórias da digitalização: músicos e materiais nas redes sociotécnicas da indústria fonográfica brasileira. Dissertação de Mestrado, Museu Nacional, Universidade Federal do Rio de Janeiro. . 2017. "Entre música e tecnologia: condições de existência e funcionamento da indústria fonográfica brasileira no século XXI". Comunicação e Sociedade, 31: 311-326.

WILLIAMS, Raymond. 1979. Marxismo e literatura. Rio de Janeiro: Zahar.

Lidiane Freitas de Barros

Federal University of Mato Grosso, Caleidoscópio (Study Group on Popular Culture), Cuiabá/MT, Brazil. E-mail: lidianefbarros@gmail.com

\section{Patricia Silva Osório}

Federal University of Mato Grosso, Department of Anthropology, Cuiabá/MT, Brazil.

E-mail: patricia.osorio@gmail.com

Juliana Braz Dias

University of Brasilia, Department of Anthropology, Brasília/DF, Brazil.

E-mail: jbrazdias@hotmail.com 